\author{
JERZY WIATER \\ Zakład Biologii i Obrazowania Komórki \\ Instytut Zoologii i Badań Biomedycznych \\ Uniwersytet Jagiellonski $w$ Krakowie \\ Gronostajowa 9, 30-387 Kraków \\ E-mail: jerzy.wiater@uj.edu.pl
}

\title{
CZY DZIECKI METODOM INŻYNIERII GENETYCZNEJ KSENOTRANSPLANTACJA STANIE SIE FAKTEM? TRANSGENICZNE ŚWINIE JAKO POTENCJALNI DAWCY NARZĄDÓW DLA CZłOWIEKA
}

\section{WPROWADZENIE}

Niedostatek organów i tkanek do przeszczepów od zmarłych dawców stanowi obecnie poważny problem $\mathrm{w}$ transplantologii. W wyniku rosnacej średniej długości życia ludzi wzrasta liczba pacjentów cierpiących na choroby przewlekłe oraz schyłkowa niewydolność narządową. Co więcej, niewydolność narządów występuje także u noworodków i niemowląt. Obecne zapotrzebowanie na narzady, tkanki i komórki do transplantacji znacznie przewyższa liczbę dostępnych dawców. Listy pacjentów oczekujacych na przeszczep (np. serca, nerki, watroby, wysepek Langerhansa) $z$ roku na rok dramatycznie się wydłużaja. Według danych Poltransplantu w 2014 r. w Polsce liczba pacjentów oczekujących na przeszczep była znacznie większa niż liczba wykonanych transplantacji (Tabela 1) (PoltransplanT 2015). Z kolei w Stanach Zjednoczonych Ameryki Północnej, jak podaje baza danych Organ Procurement and Transplantation Network, średnio co 10 minut dodawana jest kolejna osoba do listy pacjentów oczekujących na przeszczep (OPTN 2017). Współczesna transplantologia, mimo wielu sukcesów m.in. udanego wprowadzenia przeszczepu nerki i wattroby od spokrewnionego dawcy, wciąz boryka się $z$ problemem zbyt małej liczby dawców względem liczby pacjentów oczekujących na przeszczep. Niestety, co roku wielu pacjentów umiera nie doczekawszy przeszczepu.
Czy istnieja zatem jakieś alternatywy dla ludzkich narzadów i komórek? Liczne postępy w biologii komórek macierzystych oraz inżynierii tkankowej daja spore nadzieje, jednak kliniczne zastosowanie tych technik na masowa skalę to jednak wciąż odległa przyszłość. Ksenotransplantacja, czyli przeszczep międzygatunkowy, wydaje się być odpowiedzią na współczesny niedobór organów. Wykorzystanie zwierzat jako łatwo dostępnego źródła narządów, tkanek i komórek do transplantacji mogłoby $\mathrm{w}$ przyszłości uratować życie setek pacjentów na całym świecie (CIERPKA i BUDZIŃSKI 2013). W minionym wieku zarejestrowano niewielka liczbę prób klinicznego zastosowania narządów pochodzenia zwierzęcego. Wyniki większości zabiegów były niesatysfakcjonujace, ale małe światełko $\mathrm{w}$ tunelu dały badania, w których watroba pawiana funkcjonowała w organizmie człowieka około 70 dni, a nerki nawet 9 miesięcy (Collins 2003). Wyniki tych badań skłoniły wiele zespołów badawczych do poszukiwania przyczyny odrzucenia przeszczepu międzygatunkowego i do znalezienia optymalnego dawcy.

\section{KSENOTRANSPLANTACJA - KRÓTKI RYS HISTORYCZNY}

Ksenotransplantacja to procedura przeszczepu, implantacji lub infuzji do organizmu człowieka żywych komórek, tkanek lub organów pochodzacych od innych organizmów niż człowiek (SŁOMSKI i współaut. 
Tabela 1. Wyciag $z$ Krajowej Listy Oczekujących na przeszczep w 2014 r. (POLTRANSPLANT 2015).

\begin{tabular}{lll}
\hline & $\begin{array}{l}\text { Liczba } \\
\text { pacjentów } \\
\text { oczekujących }\end{array}$ & $\begin{array}{l}\text { Liczba } \\
\text { wykonanych } \\
\text { przeszczepów }\end{array}$ \\
\hline Nerka & 2635 & $1120^{*}$ \\
Wątroba & 570 & $366^{*}$ \\
Serce & 559 & 76 \\
Trzustka i/lub wy- & 39 & $9^{* *}$ \\
spy Langerhansa & & \\
Rogówka & 3926 & 939 \\
Szpik kostny & 835 & 397 \\
\hline
\end{tabular}

* Łączna liczba przeszczepień od żywych i zmarłych dawców. ${ }^{* *}$ Liczba przeszczepień tylko trzustek (całego narządu; na komórki pacjenci nadal oczekują).

2013). Należy pamiętać jednak, że termin ksenotransplantacja nie dotyczy wszczepialnych materiałów biologicznych pochodzenia zwierzęcego, takich jak świńskie zastawki (CIERPKA i BUDZIŃSKI 2013). Przeszczep międzygatunkowy nie jest pomysłem XXI w., pierwsze doniesienia o takich zabiegach pochodza $\mathrm{z}$ lat 1900-1914. Jednak przez wiele lat metoda ta była traktowana jako pomysł szalony, bez szans na rzeczywista i skuteczna aplikację. Pionierem i jednocześnie ojcem transplantologii eksperymentalnej jest Alexis Carrel. To on jako pierwszy dokonał autogenicznego przeszczepu żył (SAMDANi 2004, Tilney 2005). Z kolejnych doniesień dowiadujemy się także, że w 1905 r. Princeteau dokonał nefrotomii jednej nerki u dziecka $z$ anurią, po czym zastapił narząd płatami nerki królika, w wyniku zabiegu chirurg uzyskał wzrost diurezy u pacjenta. Niestety dziecko zmarło po 16 dniach od zabiegu w wyniku powikłań płucnych (SAMDANI 2004). W późniejszych latach przeszczepiano pacjentom $z$ mocznica kończyny górnej, nerki od kozy, owcy, małpy, świni - niestety bez większego sukcesu (SAMDANI 2004). Znaczący wzrost przeżycia organów po przeszczepie zaobserwowano wraz $z$ wprowadzeniem pierwszego leku immunosupresyjnego, jakim była cyklosporyna. Badania te były wykonywane na naczelnych, jednak dawały nadzieję na potencjalne zastosowanie u ludzi (Collins 2003). W 1992 r. Zbigniew Religa wraz z Jeremim Czaplickim i Barbara Błońska opisali przypadek zastosowania serca świni u pacjenta cierpiącego na zespół Marfana. Przy tym zabiegu dodatkowo, oprócz klasycznych leków immunosupresyjnych, zastosowano wyciagi $\mathrm{z}$ cielęcych grasic płodowych (MICHLER
1996, TILNEY 2005). Z kolei w 1993 r. Thomas Starzl, wybitny amerykański lekarz, często nazywany „ojcem współczesnej transplantologii”, również podjął się ryzykownego zabiegu i aż dwukrotnie przeszczepił pacjentom wątrobę pochodzaca od pawiana. Jeden $z$ pacjentów chorował na AIDS i wirusowe zapalenie watroby, zatem celowo otrzymał wątrobę pawiana niewrażliwa na wirusy. Przeszczepiona watroba wytwarzała białka pawiana i inne czynniki krzepnięcia krwi konieczne do przeżycia pacjenta. Niestety, mimo leczenia chory zmarł po 70 dniach w wyniku zakażenia (ColLINS 2003). Przypadków takich jak opisane powyżej $\mathrm{w}$ historii ksenotransplantacji jest bardzo dużo. Niestety, w wyniku wielu niepowodzeń, zarzucono dalsze próby przeszczepów narządów między odległymi gatunkami.

Małpy człekokształtne, takie jak pawian czy szympans, początkowo uważane za najlepszych dawców ze względu na bliskość filogenetyczna, bardzo trudno rozmnażaja się w warunkach niewoli, posiadaja mała liczbę potomstwa, która znacznie wolniej dorasta. Dodatkowo, ich narzady sa znacznie mniejsze, co ogranicza wykorzystanie ich jedynie dla dzieci. Mimo licznych, obiecujących prób w przeszłości, potencjalne wykorzystanie narządów od szympansów czy pawianów na potrzeby ksenotransplantacji byłoby rozwiazaniem bardzo kosztownym i nieopłacalnym (REEMTSMa 1966, BAiley i współaut. 1985, STARTZL i współaut. 1993, LIPIŃSKI i współaut. 2013). W ostatnich latach coraz więcej pojawia się doniesień na temat narzadów pochodzących od genetycznie zmodyfikowanych świń (EKSER i współaut. 2012, COOPER i współaut. 2014, COOPER i BotTINo 2015). Świnia domowa filogenetycznie jest bardziej oddalona od człowieka niż małpy człekokształtne, jednak posiada wiele innych cech, które przemawiaja za wyborem tego gatunku jako optymalnego dawcy. Zgodność genetyczna świni i człowieka utrzymuje sie na poziomie $96 \%$, ponadto zarówno wielkość, jak i parametry fizjologiczne wielu organów świni sa bardzo zbliżone do ludzkich. Dodatkowo, świnia ma liczne potomstwo, które stosunkowo szybko osiaga dojrzałość (GaliLi 2001). Co więcej, świnia domowa jest gatunkiem popularnie hodowanym i stosunkowo tanim w utrzymaniu, a wykorzystanie jej narząów na potrzeby ksenotransplantacji budzi mniej kontrowersji etycznych. W 1995 r. komisja etyczna w Wielkiej Brytanii orzekła, że niedopuszczalne jest wykorzystywanie naczelnych na cele ksenotransplantacji, natomiast organy świni domowej sa wystarczające do przeprowadzania prób klinicznych z udziałem ludzi (MichleR1996). 


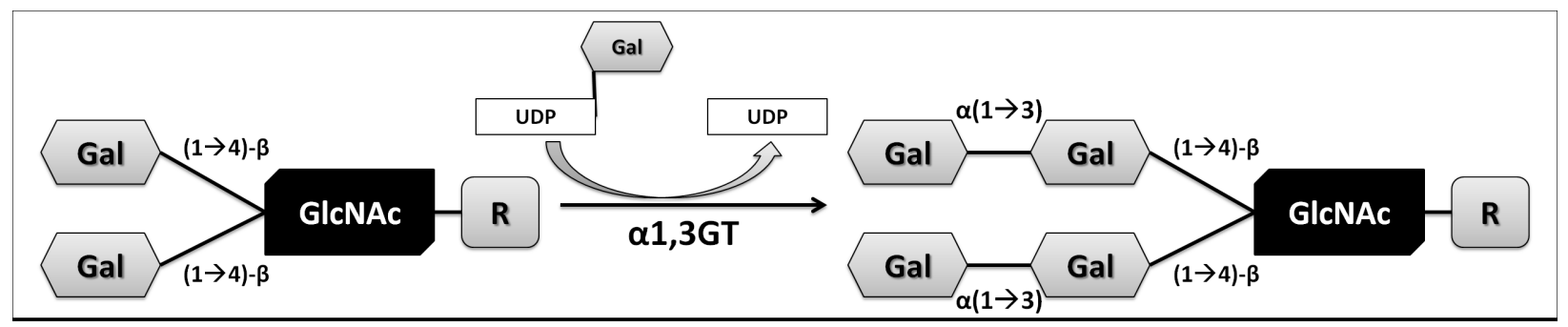

Ryc. 1. Schemat reakcji katalizowanej przez a1,3-galaktozylotransferazę.

Gal - galaktoza; GlcNAc - N-acetyloglukozamina; a1,3GT - a1,3-galaktozylotransferaza; UDP-Gal - urydyno-5'-difosforan galaktozy; UDP - urydyno-5'-difosforan; $\mathrm{R}$ - reszta białkowa

\section{KSENOTRANSPLANTACJA - BARIERA IMMUNOLOGICZNA}

Mimo dużych podobieństw między świnia a człowiekiem, zarówno na poziomie genetycznym, jak i fizjologicznym, dystans filogenetyczny jest przyczyną bariery immunologicznej. Na powierzchni większości komórek świni występuje struktura cukrowa Gala $(1,3)$ Gal $\beta(1,4)$ GlcNA-R, nazywana popularnie epitopem a-gal (lub epitopem gal) (GALILI współaut. 1984). Epitop a-gal syntetyzowany jest przez a1,3-galaktozylotransferazę (a1,3GT), enzym kodowany przez gen GGTA1. a1,3GT katalizuje reakcję przyłączenia, wiazaniem a1-3 glikozydowym, czasteczki galaktozy z UDP-Gal do glikosfingolipidów lub glikoprotein, które zawieraja końcowe reszty Galß $(1,4) G l c N A c-R$ (Ryc. 1) (BLANKEN i współaut. 1985). Epitop a-gal występuje również u innych ssaków, a także bakterii i pierwotniaków (GALILI i współaut. 1988a, COOPER i współaut. 1993). Z kolei człowiek i małpy człekokształtne w wyniku ewolucji utraciły epitop a-gal i wytwarzaja naturalne przeciwciała skierowane przeciwko tej strukturze (GAliLi i współaut. 1988a, b). Prawdopodobnie już u przodków człowieka i małp człekokształtnych gen GGTA1 uległ inaktywacji (GALILI i Swanson 1991). Zespół GaLILI i współaut (1988b) pokazał, że obecność u człowieka przeciwciał skierowanych przeciwko a-gal, jest konsekwencja immunizacji antygenami bakterii naturalnie zasiedlajacych ludzki przewód pokarmowy. Przeciwciała te występują w dwóch klasach immunoglobulin: IgG i IgM, interakcja jednych i drugich $z$ epitopem a-gal prowadzi do reakcji nadostrego odrzucenia przeszczepu (ang. hyperacute rejection, HAR). Połączenie się przeciwciał IgG i IgM $z$ epitopem a-gal, powoduje $\mathrm{u}$ biorcy uruchomienie tzw. enzymatycznej kaskady dopełniacza, w wyniku czego dochodzi do lizy komórek w przeszczepionym narzadzie i tym samym do zniszczenia przeszczepu. Proces ten jest bardzo precyzyjnie kontrolowany i uczestniczy $\mathrm{w}$ nim ponad 30 białek zlokalizowanych w błonie komórkowej lub płynach tkankowych (głównie w osoczu) (GALILI 1993, SUCHANOWSKA i współaut. 2009).

Układ dopełniacza jest naturalnym mechanizmem obronnym naszego organizmu przed patogenami, stanowi element odporności nieswoistej. Dzięki układowi dopełniacza zniszczeniu ulegaja komórki pasożytnicze, bakteryjne i nowotworowe. W kaskadzie enzymatycznej najważniejsze sa anafilatoksyny: C3a, C4a i C5a, oraz kompleks atakujący błonę komórkowa (ang. membrane attack complex, MAC). Kompleks atakujaccy błonę katalizuje wprowadzenie do błony białek tworzacych w niej duże pory, przez co rozpoznana komórka ulega lizie. Natomiast anafilatoksyny maja właściwości chemotaktyczne w stosunku do monocytów, komórek tucznych, wszystkich granulocytów, sa zdolne do uwalniania czynników prozapalnych, a także zwiększaja właściwości fagocytarne komórek żernych (MCCURRY i współaut. 1995).

Aktywacja układu dopełniacza może zachodzić na trzy sposoby: szlakiem klasycznym, alternatywnym lub lektynowym. Szlak klasyczny rozpoczyna się od związania przeciwciał IgM i/lub IgG $z$ antygenem (w tym także $z$ epitopem a-gal), dochodzi do utworzenia tzw. kompleksu immunologicznego. Następnie do takiego kompleksu przyłącza się białko C1. Białko to składa się $z$ trzech podjednostek: $\mathrm{C} 1 \mathrm{q}, \mathrm{C} 1 \mathrm{r}$ i $\mathrm{C} 1 \mathrm{~s}$, oraz jest proenzymem kontrolowanym przez inhibitor C1. W momencie przyłączenia się kompleksu immunologicznego do podjednostki $\mathrm{C} 1 \mathrm{q}$, następuje zniesienie działania inhibitora $\mathrm{C} 1$, $\mathrm{w}$ wyniku czego obserwowana jest zmiana konformacji białka $\mathrm{C} 1$ i przekształcenie go do aktywnej proteazy serynowej. Białko C1 uruchamia kaskadowy szlak dopełniacza, przez trawienie składnika C4 (MCCURRY i współaut. 1995, LIPIŃSKI i współaut. 2013).

Białko C1 może być aktywowane bez udziału przeciwciał; ma to miejsce w lektynowym szlaku aktywacji układu dopełniacza. Lektyna wiążąca mannozę (ang. man- 
nan binding lectin, MBL) wystepuje w surowicy krwi i jest zdolna do wiazania się $z$ końcowymi grupami mannozy obecnymi na powierzchni komórek bakterii. MBL zmienia konformację C1 i aktywuje proenzym MASP (ang. MBL associated serine protease), który trawi składnik $\mathrm{C} 4 \mathrm{i}$ tym samym uruchamia kaskadę enzymatyczna dopełniacza (LIPIŃsKI i współaut. 2013).

Trzecia $z$ dróg aktywacji kaskady dopełniacza to tzw. szlak alternatywny, niezwykle istotny, gdy organizm atakuja drobnoustroje; stanowi pierwsza linię obrony zanim pojawia się specyficzne przeciwciała. Szlak alternatywny aktywowany jest przez niski poziom składnika C3 w surowicy krwi. W wyniku licznych przekształceń składnika C3 w szla$\mathrm{ku}$ alternatywnym powstaje konwertaza C5, która włączana jest do kaskady dopełniacza (MCCURRY i współaut. 1995, LIPIŃSKI i współaut. 2013).

Na końcu enzymatycznej kaskady dopełniacza tworzy się kompleks MAC, który katalizuje przyłączenie się do błony komórkowej kolejnych czynników kaskady dopełniacza. Ostatecznie dochodzi do podziurawienia błony komórkowej i zniszczenia rozpoznanej komórki (LIPIŃSKI i współaut. 2013).

\section{KSENOTRANSPLANTACJA A RYZYKO WIRUSÓW ODZWIERZECYCH}

Z ksenotransplantacja zwiazane jest również ryzyko przeniesienia na człowieka wirusów odzwierzecych. Ryzyko to rośnie wraz z malejaca odległościa filogenetyczna między dawca a biorca ksenoprzeszczepu. Zatem i w tym przypadku wybór świni domowej jako potencjalnego dawcy wydaje się być bardziej uzasadniony. Zbieżność genetyczna między świnią a człowiekiem jest nieco mniejsza niż między małpami człekokształtnymi a człowiekiem. Mimo to nie można wykluczyć takiego ryzyka i dlatego też prowadzone sa intensywne badania nad potwierdzeniem i/lub wykluczeniem obecności tzw. PERV (ang. porcine endogenous retroviruses) w organizmie świń transgenicznych, wykorzystywanych jako modele do badań nad ksenotransplantacja. Badania te maja na celu określenie m.in. stopnia inwazyjności oraz prawdopodobieństwa transmisji PERV od świń do organizmu człowieka (MAZUREK i współaut. 2014, KIMSA i współaut. 2015).

PERV należą do rodzaju Gammaretrovirus, ich genom, podobnie jak większości retrowirusów, zbudowany jest $z$ trzech genów: gag (ang. group-specyfic antigen), pol (ang. polymerase) i env (ang. envelope). Na etapie prowirusowego DNA geny te sa ograniczone przez tzw. LTR (ang. long terminal repeats), czyli długie niekodujace powtórzenia końco- we. Powtórzenia te zawieraja promotor, enhancer i elementy regulatorowe. Gen gag koduje białka strukturalne, m.in. budujace kapsyd wirusa i jego macierz wewnętrzna. Gen pol koduje własną polimerazę wirusa, która jest odwrotna transkryptaza. Natomiast gen env koduje transbłonowe białka envelope (TM) oraz powierzchniowe białka envelope (SU), które zawieraja domenę wiążaca receptor. Wewnątrz tej domeny można wyróżnić dwa zmienne regiony, które decyduja m.in. o podtypie PERV (LE TISSIER i współaut. 1997, WILSON i współaut. 2000, GEMENIANO i współaut. 2006, DENNER 2010). Dwa $z$ podtypów PERV: PERV-A i PERV-B występują u wszystkich świń (DENNER i TÖNJES 2012). Obydwa podtypy należą do tzw. politropowych retrowirusów i mają zdolność zakażania ludzkich komórek. Trzeci $z$ podtypów, PERV-C, występuje u większości świń i ma zdolność do replikacji wyłącznie w komórkach świni. Jednak sa potwierdzone przypadki, kiedy PERV-A ma zdolność do rekombinacji $z$ PERV-C i taki zrekombinowany PERV-A/C retrowirus posiada już zdolność do infekcji komórek ludzkich (BARTOSCH i współaut. 2004, HARRISON i współaut. 2004, DENNER 2008).

Zdolność do infekcji ludzkich komórek przez PERV potwierdzono do tej pory w badaniach in vitro, jednak zjawisko to nie było obserwowane in vivo. $\mathrm{Z}$ kolei $\mathrm{w}$ badaniach na myszach potwierdzono możliwość transmisji PERV in vivo. Nie wyjaśnione sa również konsekwencje takiej infekcji dla człowieka. Podejrzewa się, że PERV moga prowadzić do spontanicznych mutacji w genomie, jednak ta hipoteza jest wciąz niepotwierdzona (MAZUREK i współaut. 2014).

Wobec powyższego, niezmiernie ważne sa badania na obecność wszystkich podtypów PERV u świń, które mają zostać wykorzystane jako potencjalni dawcy komórek, tkanek czy narzádów do ksenotransplantacji. Niestety, nie jest możliwe uzyskanie świń zupełnie pozbawionych PERV, jednak dzięki badaniom molekularnym istnieje możliwość wyselekcjonowania tych osobników, które odznaczaja się najniższą ekspresją PERV w swoim genomie (MAZUREK i współaut. 2014).

\section{REGULACJA UKŁADU DOPEŁNIACZA}

Rozwiazanie problemu nadostrego odrzucenia przeszczepu $z$ udziałem układu dopełniacza moga stanowić świnie transgeniczne $z$ wprowadzonymi ludzkimi genami regulującymi kaskadę dopełniacza (MCCURRY i współaut. 1995). W wyniku ewolucji rozwinęly się precyzyjne mechanizmy kontroli układu dopełniacza, ponieważ może on ulegać spontanicznej aktywacji i atakować 
własne komórki. Regulatory te należą do rodziny białek strukturalnie i funkcjonalnie podobnych do siebie. Jedne $z$ nich blokuja aktywację kaskady dopełniacza, inne natomiast nie dopuszczaja do formowania się kompleksu MAC. Część $z$ tych białek związana jest $z$ błona komórkowa (CR1, CD55, MCP, CD59), inne zaś występują w osoczu (czynnik $\mathrm{H}, \mathrm{C} 4 \mathrm{bp}$, inhibitor $\mathrm{C} 1$, karboksypeptydaza $\mathrm{N}$, białko $\mathrm{S}$, klasteryna). Ważne Z punktu widzenia ksenotransplantacji sa czynniki: CD55, MCP i CD59 (LE BAS-BERNARDET i współaut. 2011).

Czynnik CD59 (inaczej MIRL, ang. membrane inhibitor of reactive lysis) hamuje tworzenie się kompleksu MAC. Prawdopodobnie CD59 blokuje polimeryzacje czynnika C9 oraz nie pozwala na przyłączenie się kompleksu do błony komórkowej (SACKS i ZHOU 2012). Dzięki temu czynnik CD59 chroni komórki przed degradacja przez układ dopełniacza. Poczatkowo w badaniach in vitro wykazano, że stała ekspresja CD59 w linii komórkowej CHO (ang. Chinese hamster ovary cells; komórki wyizolowane $z$ jajnika chomika chińskiego) chroni te komórki przed atakiem układu dopełniacza, a stopień ochrony zależy od poziomu ekspresji na powierzchni komórek (FODOR i współaut. 1994). W późniejszych badaniach udało się uzyskać transgeniczne myszy i świnie $z$ ekspresja CD59 (DIAMOND i współaut. 1996, CHEN i współaut. 1999, NIEMANN i współaut. 2001). Dwie grupy badawcze pokazały niezależnie, że czynnik CD59 zabezpiecza przed atakiem kaskady dopełniacza zarówno organy zwierząt poddane perfuzji ex vivo (NIEMANN i współaut. 2001), jak i organy przeszczepione pawianom (CHEN i współaut. 1999). Inna grupa wykazała, że ludzki czynnik CD59 nie ma negatywnego wpływu na organizm świni (DEPPENMEIER i współaut. 2006).

Czynnik CD55 (inaczej DAF; ang. decay accelerating factor), czyli czynnik przyspieszajacy rozkład, steruje podatnością komórek na atak układu dopełniacza (SACKS i ZHOU 2012). CD55 blokuje tworzenie się kompleksu konwertaz C3 i C5 i powoduje dysocjację uformowanego kompleksu. Wykazano w badaniach ex vivo, że wprowadzenie do genomu świni dodatkowych kopii genu kodującego czynnik CD55, chroni niektóre swinie przed atakiem ludzkiego układu dopełniacza (WATERWORTH i współaut. 1998, Cozzi i współaut. 2000, DiAMOND i współaut. 2001).

Czynnik MCP (ang. membrane cofactor protein), inaczej błonowy kofaktor białkowy, podobnie jak CD55, hamuje tworzenie się kompleksu konwertazy C3, tym samym działa zarówno w szlaku klasycznym, jak i alternatywnym aktywacji układu dopełniacza. Jego ekspresja na powierzchni komórek, chroni je przed atakiem dopełniacza. W badaniach przeprowadzonych $z$ udziałem pawianów wykazano, że ekspresja MCP w organach świń chroni je przed atakiem układu dopełniacza pawiana (LOVELAND i współaut. 2004, SACKS i ZHOU 2012).

\section{TRANSGENICZNE ŚWINIE Z OBNIŻONĄ EKSPRESJA EPITOPU A-GAL}

Omówione wcześniej modyfikacje geno$\mathrm{mu}$ świni domowej pokazuja jedna $z$ moźliwych strategii wyciszenia nadostrej reakcji immunologicznej. Inną możliwościa jest modyfikacja białek powierzchniowych komórek świni w taki sposób, aby obniżyć ilość epitopu a-gal. Modyfikacji takiej można dokonać przez inaktywację $\mathrm{w}$ genomie świni genu GGTA1 lub przez wprowadzenie do tego genomu ludzkich genów kodujacych białka obniżające ilość epitopu a-gal.

Inżynieria genetyczna dysponuje obecnie sporym orężem niezbędnym do precyzyjnego usunięcia konkretnego genu $\mathrm{Z}$ genomu. W celu wykonania określonych modyfikacji genetycznych, wykorzystuje się naturalnie występujące endonukleazy, czyli tzw. enzymy restrykcyjne, rozpoznajace określone sekwencje DNA, a następnie wycinające rozpoznany fragment. Doskonałym przykładem takich enzymów sa miejscowo specyficzne nukleazy $z$ motywem „palca cynkowego” oraz nukleazy typu TALEN (ang. transcription activator-like effector nucleases).

Nukleaza $z$ motywem "palca cynkowego" (ang. zinc finger nuclease, $\mathrm{ZFN}$ ) jest sztucznie skonstruowanym enzymem restrykcyjnym. Powstała w wyniku połączenia motywu „palca cynkowego” z domena, która przecina nić DNA (BITINAITE i współaut. 1998, MILLER i współaut. 2007). Motyw „palca cynkowego" to specjalna struktura białkowa, zdolna do wiazania nici DNA. Nazwa „palec cynkowy" oddaje wygląd tej czasteczki, ponieważ kształtem przypomina ona ludzki palec. Z kolei „cynkowy”, ponieważ w centralnej jego części znajduje się atom cynku, który pełni rolę stabilizatora całej struktury. Brak atomu cynku sprawia, że struktura rozpada się i traci swoją funkcję (MILlER i współaut. 2007). Motyw „palca cynkowego" jest niezbędny tam, gdzie musi dojść do rozpoznania unikatowej sekwencji DNA. „Palce cynkowe" to najbardziej charakterystyczna struktura wielu czynników transkrypcyjnych. Dzięki tej domenie czynniki transkrypcyjne moga pełnić swoja funkcję $z$ wielka precyzja, rozpoznawać konkretny region nici DNA, wiązać się $z$ nim i kontrolować proces transkrypcji. Człowiek stara się naślado- 


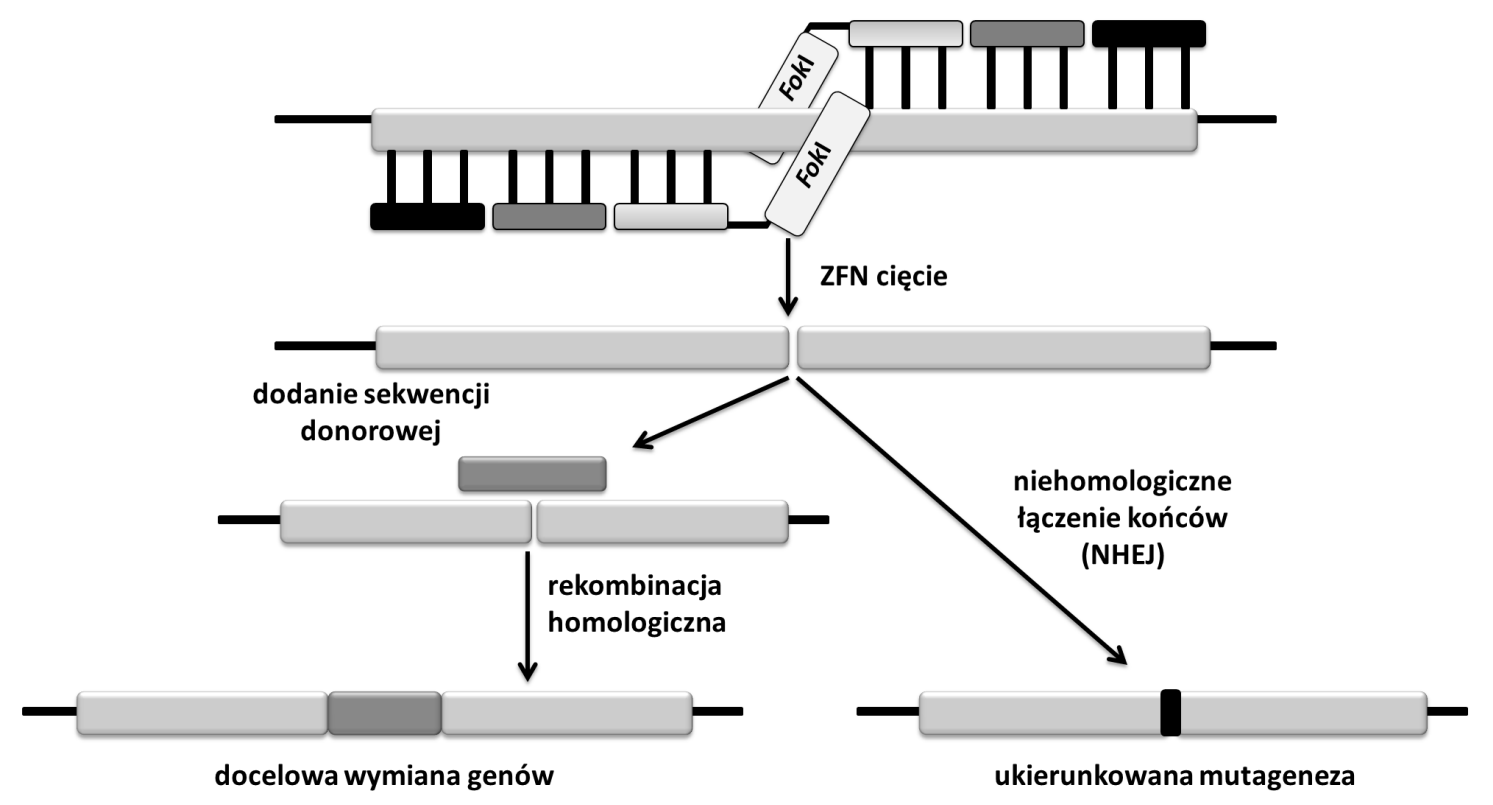

Ryc. 2. Schemat działania nukleazy z motywem „palca cynkowego” (ZFN).

wać naturę, dlatego i ten mechanizm został zaadaptowany na nasze potrzeby - tak powstało precyzyjne narzędzie tnace nić DNA $\mathrm{w}$ interesujacym nas miejscu. Nukleaza $\mathrm{z}$ motywem "palca cynkowego" zbudowana jest $z$ domeny tnacej nić DNA pochodzacej od endonukleazy FokI oraz motywu „palca cynkowego". Domena endonukleazy FokI naturalnie występuje w postaci monomeru (pojedynczej struktury), jednak do całkowitego przecięcia nici DNA wymagana jest dimeryzacja (połaczenie się dwóch takich samych struktur) (DURAI i współaut. 2005). Mówiąc prościej, enzym ten działa jak nożyczki, bo do pełnego przecięcia nici DNA potrzebuje dwóch takich samych elementów, ustawionych naprzeciw siebie (Ryc. 2). Część odpowiedzialna za rozpoznanie konkretnej sekwencji DNA stanowia trzy trójki nukleotydowe. Dzięki takiemu układowi istnieje możliwość precyzyjnego zaprojektowania „palców cynkowych" rozpoznajacych interesujacca nas sekwencję DNA.

TALEN (ang. transcription activator-like effector nucleases) jest kolejna $z$ metod inżynierii genetycznej, pozwalająca precyzyjnie edytować genom. Zasada działania systemu TALEN jest analogiczna do ZFN, główną różnice stanowią elementy rozpoznajace sekwencje DNA, które wiąża się do pojedynczych nukleotydów (Ryc. 3), a nie do całych trójek, jak to ma miejsce w ZFN (Christian i współaut. 2010). Prostsza budowa domeny rozpoznajacej DNA jest cecha charakterystyczna dla nukleaz TALE. Układ ten pozwala na łatwiejsza modyfikację domeny rozpoznajacej DNA, rozszerzając tym samym możliwości aplikacyjne tej metody. System TALEN został zaadaptowany od bakterii Xantomonas atakujacych rośliny (KAY i współaut. 2009, BOCH i BONAS 2010).

Jednym $z$ najmłodszych systemów ukierunkowanej mutagenezy majacej na celu edycję genomu jest system CRISPR/Cas9 (ang. clustered regularly interspaced short palindromic repeats, co tłumaczy się na język polski jako zgrupowane, regularnie rozproszone, krótkie, powtarzające się sekwencje palindromowe). System ten stanowi niejako rodzaj układu odpornościowego bakterii m.in. u Streptococcus pyogenes, zabezpiecza bakterie przed infekcja obcym DNA, np. fagowym lub plazmidowym. Endonukleaza Cas9 kodowana jest w genomowym locus CRISPR. Za rozpoznanie konkretnej sekwencji DNA oraz zwiazanie się nukleazy odpowiada krótka sekwencja PAM (ang. protospacer adjacent motif). Dodatkowo w skład kompleksu Cas9 wchodza dwie małe, niekodujace czasteczki RNA tzw. CRISPR RNA (crRNA) oraz transaktywujace crRNA (tracrRNA). Krótkie RNA pozwalają białku Cas9 na rozpoznanie i przecięcie konkretnego regionu DNA (BARRANGOU 2013, PENNISI 2013, CHEN i GAO 2014). Ogromna zaleta systemu CRISPR/Cas9 jest jego wysoka specyficzność i prostota w projektowaniu konstruktu, która zależny głównie od 20 par zasad budujacych gRNA (guide RNA). Co więcej, nukleaza Cas9 nie wymaga szczególnych zmian i sprawdziła się do tej pory $w$ wielu badanych układach. Oprócz tego możliwość multipleksowania i uzyskania ekspresji kilku syntetycznych 


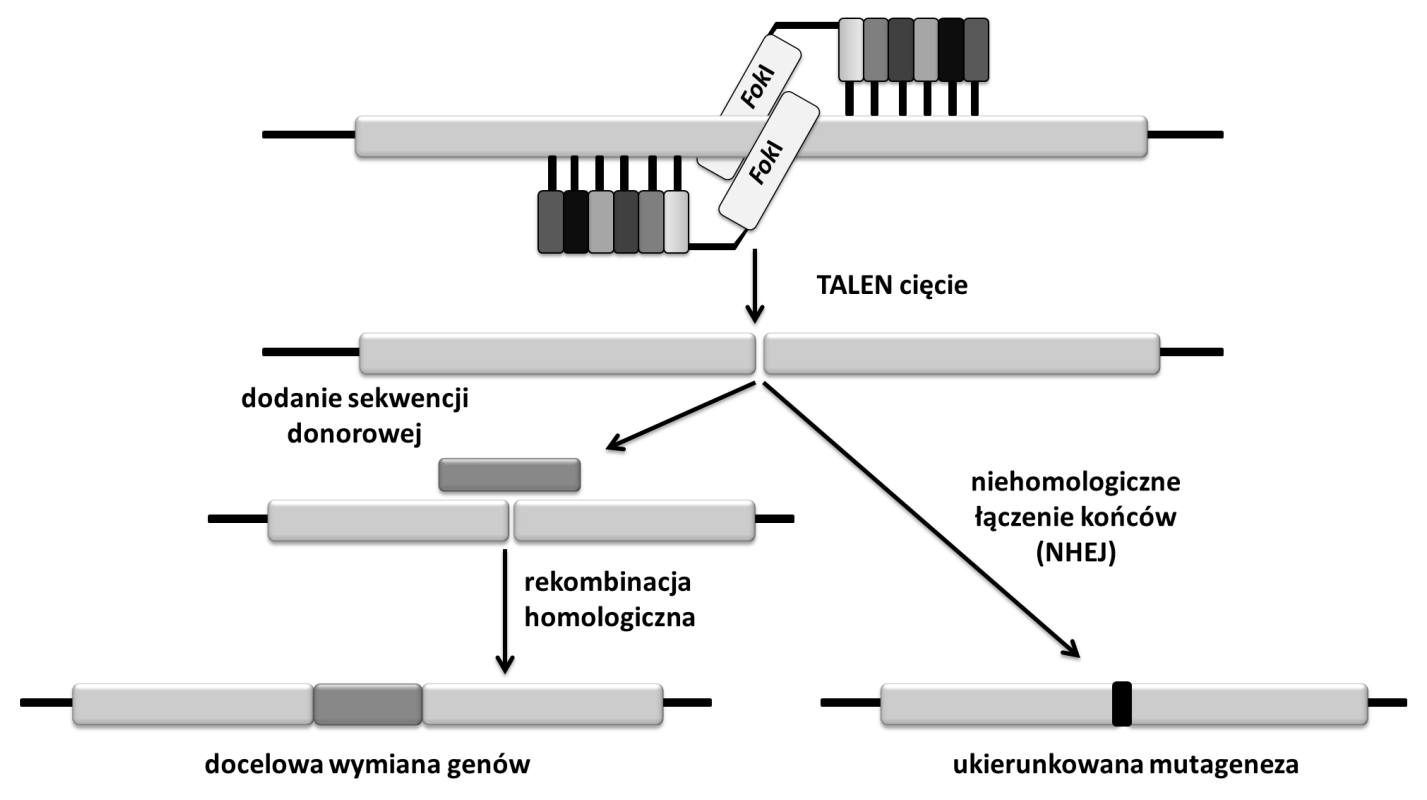

Ryc. 3. Schemat działania nukleazy typu TALEN.

RNA w ramach jednego doświadczenia pozwala skrócić czas analiz i obniżyć nakłady finansowe (CONG i współaut. 2013). Istnieje zatem duża szansa, że ten prosty i tani system w niedalekiej przyszłości stanie się podstawowa metoda uzyskiwania genetycznie modyfikowanych zwierząt. Omówione powyżej metody opierają się na strategii inaktywacji genu GGTA1 kodującego a1,3galakozylotransferazę. Każda $z$ tych metod można to osiagnąć $z$ różna specyficznościa i wydajnościa (Tabela 2).

Inna ze strategii usunięcia epitopu a-gal z powierzchni komórek świni opiera się na wprowadzeniu do jej genomu, za pomocą metody mikroiniekcji, ludzkich genów FUT2 i/lub GLA. Mikroiniekcja polega na wstrzyknięciu zaprojektowanej wcześniej sekwencji DNA do męskiego przedjąrza zygoty. Procedurę ta przeprowadza się pod kontrola specjalnego mikromanipulatora. Aparat ten w uproszczeniu składa się $z$ mikroskopu, specjalnej pipety, za pomoca której przytrzymuje się zygotę oraz mikroigły iniekcyjnej, dzięki której możliwe jest precyzyjne wprowadzenie sekwencji DNA do zygoty. Metoda ta jest niestety mało wydajna, ale jak na razie najbardziej skuteczna.

Gen FUT2 koduje a1,2-fukozylotransferazę (a1,2FT), która odpowiada za syntezę tzw. struktury $\mathrm{H}$, rdzeniowego składnika grup krwi układu ABO. Modyfikacja ta opiera się na konkurencji dwóch enzymów o ten sam substrat i ma na celu zablokowanie syntezy epitopu a-gal. Zarówno endogenna a1,3GT, jak i wprowadzona a1,2FT do syntezy specyficznych dla sie- bie epitopów wykorzystują $\mathrm{N}$-acetylolaktozoaminę (N-lac). Aktywność a1,2FT u świni transgenicznej powoduje obniżenie ilości epitopu a-gal na powierzchni komórek. Jak to jest możliwe? Obydwa enzymy występuja w aparacie Golgiego, przy czym a1,2FT w części cis, natomiast a1,3GT w części trans. Zatem N-lac wcześniej wystawiony jest na działanie a1,2FT, która przyłącza do niego cząsteczkę fukozy, a tak powstały kompleks nie posiada już wolnych wiązań do przyłączenia cząsteczki galaktozy w reakcji katalizowanej przez a1,3GT. W wyniku tej reakcji zamiast epitopu a-gal na powierzchni komórek świni powstaje ludzka struktura H, która prawdopodobnie może dodatkowo rozwiązać problem opóźnionego odrzucenia ksenoprzeszczepu (Ryc. 4A) (LIPIŃSKI i współaut. 2010).

Kolejna $z$ możliwości, pozwalająca na zredukowanie liczby czasteczek a-gal na powierzchni komórek świni, wykorzystuje ludzką a-galaktozydazę, enzym kodowany przez gen GLA. a-Galaktozydaza katalizuje reakcję odcięcia końcowych reszt D-galaktozy $z$ epitopu a-gal (Ryc. 4B). Pozbawienie epitopu a-gal galaktozy sprawia, że staje się on "niewidzialny" dla przeciwciał (mniej ksenoreaktywny), tym samym dochodzi do obniżenia nadostrej reakcji immunologicznej zależnej m.in. od układu dopełniacza. Przeprowadzone in vitro badania pokazały, że transfekowane komórki wykazujace ekspresję ludzkiej a-galaktozydazy sa bardziej odporne na atak układu dopełniacza niż komórki kontrolne (Rys. 5A) (ZEYLAND i współaut. 2013). 
Tabela 2. Porównanie efektywności metod ZFN, TALEN oraz CRISPR/Cas9 (wg SEGA i LINKIEWICZ 2014, zmieniona)

\begin{tabular}{|c|c|c|c|}
\hline & ZFN & TALEN & CRISPR/Cas9 \\
\hline Charakterystyka & $\begin{array}{l}\text { Długość sekwencji } 18-30 \mathrm{pz} \\
\text { Dwa monomery - 3-6 mo- } \\
\text { dułów } \\
\text { Każdy moduł wiąże tryplet } \\
\text { DNA i nukleaze FokI } \\
\text { Kompleks białko-DNA }\end{array}$ & $\begin{array}{l}\text { Długość sekwencji 50-60 pz } \\
\text { Dwa monomery } 13-30 \text { mo- } \\
\text { dułów } \\
\text { Każdy moduł wiąże } 1 \mathrm{pz} \\
\text { DNA i nukleazę FokI } \\
\text { Kompleks białko-DNA }\end{array}$ & $\begin{array}{l}\text { Długość sekwencji do } 20 \mathrm{pz} \\
\text { Łączenie RNA oraz DNA przy } \\
\text { udziale transkryptu naprowa- } \\
\text { dzającego i nukleazy Cas9 } \\
\text { Kompleks RNA-DNA }\end{array}$ \\
\hline Zalety & $\begin{array}{l}\text { technika bardzo dobrze po- } \\
\text { znana } \\
\text { duża liczba baz danych se- } \\
\text { kwencji i narzędzi bioinfor- } \\
\text { matycznych } \\
\text { możliwość oceny aktywności } \\
\text { niedocelowej na genom }\end{array}$ & $\begin{array}{l}\text { prosta budowa domeny wia- } \\
\text { żącej DNA } \\
\text { łatwość projektowania } \\
\text { niski poziom efektów niedo- } \\
\text { celowych w genomie } \\
\text { niższa cytotoksyczność } \\
\text { w porównaniu ZFN } \\
\text { stosunkowo niski koszt uzy- } \\
\text { skania }\end{array}$ & $\begin{array}{l}\text { możliwość precyzyjnego określe- } \\
\text { nia rejonu cięcia DNA } \\
\text { prosta budowa - jedno białko i } \\
\text { elastyczna cząsteczka RNA } \\
\text { najniższy koszt uzyskania } \\
\text { najkrótszy czas projektowania } \\
\text { dynamiczny rozwój metody }\end{array}$ \\
\hline Wady & $\begin{array}{l}\text { bardzo ograniczone możli- } \\
\text { wości ukierunkowania na } \\
\text { konkretne locus } \\
\text { brak palców cynkowych dla } \\
\text { wszystkich trójek nukleoty- } \\
\text { dów } \\
\text { trudne projektowanie } \\
\text { najwyższy koszt uzyskania }\end{array}$ & $\begin{array}{l}\text { metoda zależna epigenetycz- } \\
\text { nie } \\
\text { wieloznaczny moduł rozpo- } \\
\text { znający guaninę }\end{array}$ & $\begin{array}{l}\text { bardzo wysoki poziom efektów } \\
\text { niedocelowych na genom (mu- } \\
\text { tacje) } \\
\text { brak informacji o cyto- } \\
\text { i genotoksyczności tej metody } \\
\text { mała liczba baz danych sekwen- } \\
\text { cji }\end{array}$ \\
\hline $\begin{array}{l}\text { Perspektywy za- } \\
\text { stosowania u } \\
\text { świni }\end{array}$ & +++ & ++++ & +++++ \\
\hline
\end{tabular}

Dla zintensyfikowania efektu sugeruje się uzyskiwanie świń podwójnie transgenicznych, posiadajacych w swym genomie zarówno gen FUT2, jak i GLA. Niestety ze względu na liczne ograniczenia metody mikroiniekcji, m.in. brak możliwości jednoczesnego prowadzenia dwóch konstruktów, stosuje się krzyżowanie świń pojedynczo transgenicznych, tym samym uzyskujac swinie FUT2 $\times$ GLA. Strategia ta opiera się niejako na działaniu $z$ dwóch stron w komórce, od wnętrza a1,2-fukozylotransferaza blokuje syntezę epitopu a-gal, natomiast od zewnattrz a-galaktozydaza dezaktywuje pozostałą część epitopu a-gal, który mimo wszystko powstał. Trzeba mieć na uwadze fakt, że ilość N-lac jest ograniczona w komórce, jednak nie na tyle, by a1,3GT nie przekształciła części w epitop a-gal (ZEYLAND i współaut. 2014).

\section{KOMÓRKOWY MECHANIZM ODRZUCENIA KSENOPRZESZCZEPU A SYSTEM KRZEPNIECIA KRWI}

Oprócz problemów $z$ epitopem a-gal przy ksenotransplantacji wystepuje jeszcze ryzyko niezgodności tkanek świni na poziomie białek klasy MHC. W badaniach in vitro wykazano, że obecność ludzkiego genu HLA-E w komórkach śródbłonka świni chroni je przed zniszczeniem przez komórki NK ludzkiego układu odpornościowego (LILIENFELD i współaut. 2007). Uzyskano zatem świnie $z$ ekspresją ludzkiego genu HLA-E, a modyfikacja ta była możliwa również dzięki mikroiniekcji DNA. Gen ten, tak jak i poprzednie omawiane, został wprowadzony pod kontrola promotora ogólno-tkankowego tak, aby jego ekspresja zachodziła w większości, jeśli nie we wszystkich narzadach świni (BOKSA i współaut. 2015). 


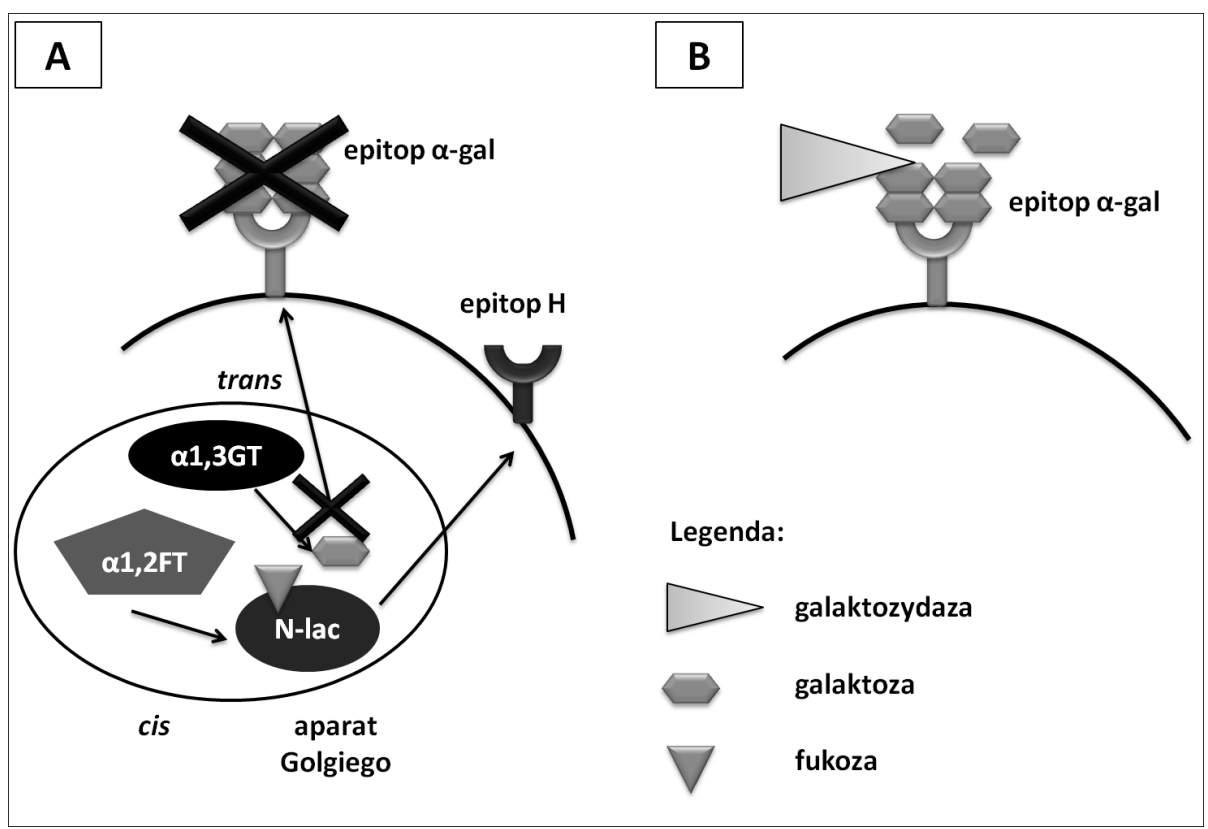

Ryc. 4. Schemat działania strategii transgenezy świń opartych o: (A) ludzką a1,2-fukozylotransferazę, (B) ludzką a-galaktozydazę.

a1,3GT - a1,3-galakozylotransferaza; a1,2FT - a1,2-fukozylotransferaza; N-lac - N-acetyloglukozamina.

Dużą rolę w odrzuceniu ksenoprzeszczepu odgrywaja również makrofagi (CADILI i KNETEMAN 2008). Aktywacja makrofagów może zachodzić na dwa sposoby: (i) jako odpowiedź na oddziaływanie ksenoreaktywnych limfocytów T lub (ii) w wyniku bezpośrednich interakcji między antygenami obecnymi w śródbłonku dawcy, a receptorami powierzchniowymi makrofagów biorcy (YI i współaut. 2003). Czynnikiem, który hamuje fagocytoze jest antygen powierzchniowy CD47. Jednakże CD47 świni różni się od ludzkiego, przez co nie jest właściwie rozpoznawany przez receptor SIRPa (ang. signal-regulatory protein a), w konsekwencji dochodzi do aktywacji makrofagów. Rozwiązaniem tego problemu mogło by być uzyskanie transgenicznych świń $z$ wprowadzonym ludzkim genem kodującym czynnik CD47 (IDE i współaut. 2007).

Innym, nie mniej ważnym czynnikiem odpowiedzialnym za odrzucenie ksenoprzeszczepu jest system krzepnięcia krwi, a w szczególności zaburzenia w jego regulacji wynikające $z$ pewnych różnic genetycznych między świnią a człowiekiem. Proces krzepnięcia krwi, jako reakcja na uraz, jest ściśle regulowany przez wiele czynników. System krzepnięcia wymaga precyzyjnej kontroli, aby zapobiegać spontanicznym krwotokom czy zakrzepom. W systemie krzepnięcia uczestniczy wiele czynników aktywujących, jak i hamujacych ten proces. Do grupy inhibitorów układu krzepnięcia krwi należą: inhibitor szlaku czynnika tkankowego, antytrombina III, kofaktor II heparyny, białka uczestniczace w aktywacji białka C (białko C, trombina, białko S oraz trombomodulina). Inhibitor szlaku czynnika tkankowego uczestniczy w ogólnej regulacji układu krzepnięcia krwi. Trombomodulina wiąże trombinę i bierze udział w aktywacji białka C, które stanowi silny antykoagulant. $Z$ kolei białko $\mathrm{C}$, wraz $\mathrm{Z}$ białkiem $\mathrm{S}$ jako kofaktorem, hamuje enzymatyczna kaskadę układu krzepnięcia, prowadząca do powstania skrzepu. Antytrombina III hamuje aktywność czynników krzepnięcia posiadajacych resztę serynowa w swym centrum aktywnym. Wspomniane różnice genetyczne między biorca a dawca narządów moga prowadzić do zachwiania równowagi między prokoagulacyjna a antykoagulacyjną działalnościa układu krzepnięcia krwi. Konsekwencja takiej dysproporcji może być opóźnione odrzucenie ksenoprzeszczepu. Wiadomo, że trombomodulina świni dużo słabiej wiąże trombinę ludzka, tym samym nie aktywuje białka C (SIEGEL i współaut. 1997). Podobnie inhibitor szlaku czynnika tkankowego świni bardzo słabo hamuje ludzki czynnik Xa odpowiedzialny za przekształcanie protrombiny $\mathrm{w}$ trombinę (KOPP i współaut. 1997). Zespół DwYER i współaut. (2006) pokazał, że ekspresja ludzkiego CD39 u myszy zapobiega spontanicznej zakrzepicy w przypadku allogenicznych przeszczepów serc u myszy oraz perfuzji ludzka krwia mysich wysepek trzustkowych. 
Mechanizm opóźnionego odrzucenia ksenoprzeszczepu wciąż jest mało poznany. Mimo licznych badań, brak jest jednoznacznych odpowiedzi. Rozważa się możliwość otrzymania świń modyfikowanych genetycznie, zaprojektowanych tak, aby wykazywały ekspresję ludzkich genów kodujacych: CD39, trombomodulinę, czy też inhibitor szlaku czynnika tkankowego (LIPIŃSKI i współaut. 2013).

\section{PODSUMOWANIE}

Ksenotransplantacja może w przyszłości stać się w przypadku niektórych narządów, swego rodzaju pomostem dla pacjentów oczekujących na alloprzeszczep. Dzięki rozwojowi technik biologii molekularnej oraz inżynierii komórkowej, $z$ roku na rok wzrasta nasza wiedza o możliwościach wykorzystania na potrzeby ksenotransplantacji komórek, tkanek czy nawet całych narządów pochodzacych od świń transgenicznych. Do tej pory odnotowano już kilka przypadków zastosowania klinicznego biomateriałów pochodzących od tego typu zwierząt, m.in. skóra transgenicznych świń jako nowoczesny bioopatrunek, zastosowany przez Centrum Leczenia Oparzeń w Siemianowicach Śląskich, czy też świńskie zastawki serca opracowywane przez lekarzy i naukowców z Kliniki w Zabrzu. Sukcesy tych zespołów pokazuja, że materiały pochodzace od transgenicznych zwierzat maja szanse $z$ powodzeniem być zastosowane u ludzi i jednocześnie daja nadzieję na przyszła aplikację żywych narządów w zabiegach ksenotransplantacji.

\section{Streszczenie}

Ograniczona liczba dawców narządów i tkanek do przeszczepów stanowi obecnie poważny problem w transplantologii. Wielu pacjentów co roku umiera niedoczekawszy przeszczepu. Czy istnieje jakaś alternatywa dla ludzkich narządów? Wykorzystanie zwierząt jako dawców komórek, tkanek i narządów może stanowić odpowiedź na to pytanie. Jednakże wybór optymalnego gatunku jest trudny. Małpy człekokształtne, najbliższe człowiekowi, niestety nie spełniaja wielu kryteriów. Ponadto budza sporo zastrzeżeń etycznych. Świnia jako gatunek fizjologicznie i genetycznie podobny do człowieka wydaje się być dawca optymalnym. Ograniczenie jednak stanowi bariera immunologiczna, wynikajaca $z$ większego dystansu filogenetycznego między świnia a człowiekiem. Współczesna inżynieria genetyczna stara się rozwiązać ten problem. Możliwe jest uzyskanie świń transgenicznych, które posiadaja w swoim genomie ludzkie geny obniżające ryzyko niezgodności tkankowej i immunologicznej. Niniejszy artykuł stanowi przeglą dotychczasowych osiagnięć w inżynierii genetycznej świni domowej na potrzeby ksenotransplantacji. Omówiono kilka strategii rozwiązania problemu odrzucenia ksenoprzeszczepu oraz pokazano możliwe szanse i zagrożenia wynikające $z$ zastosowania materiałów pochodzenia zwierzęcego.

\section{LITERATURA}

Bailey L. L., NeHlsen-CANnarella S. L., ConcepCION W., Jolley W. B., 1985. Baboon-to-human cardic xenotransplantation in neonate. JAMA 254, 3321-3329.

BARRANGOU R., 2013. CRISPR. Cas systems and RNA-guided interference. Wiley Interdisc. Rev., RNA 4, 267-278.

Bartosch B., Stefanidis D., Myers R., Weiss R., PATIENCE C., TAKEUCHI Y., 2004. Evidence and consequence of porcine endogenous retrovirus recombination. J. Virol. 78, 13880-13890.

Bitinaite J., WAH D. A., AGgARWAL A. K., SCHILDKRAUT I., 1998. FokI dimerization is required for DNA cleavage. Proc. Natl. Acad. Sci. USA 95, 10570-10575.

Blanken W. M., VAN DEN EiJnden D. H., 1985. Biosynthesis of terminal Gal a1-3Gal a1-4Glc$N A c-R$ oligosaccharide sequences on glycoconjugates. Purifi cation and acceptor specifi city of a UDP-Gal:Nacetyllactosaminide a1-3-galactosyltransferase from calf thymus. J. Biol. Chem. 260, 12927-12934.

Boch J., BonAS U., 2010. Xanthomonas AvrBs3 family-type III effectors: discovery and function. Ann. Rev. Phytopathol. 48, 419-436.

BOKSA M., ZEYland J., SŁOMSKI R., LiPIŃSKI D. 2015. Immune modulation in xenotransplantation. Archiv. Immunol. Therap. Exp. 63, 181192.

Cadili A., Kneteman N., 2008. The role of macrophages in xenograft rejection. Transplant. Proc. 40, 3289-3293.

CHEN K., GAO C., 2014. Targeted genome modification technologies and their applications in crop improvements. Plant Cell Rep. 33, 575583.

Chen R. H., Naficy S., Logan J. S., Diamond L. E., ADAMS D. H., 1999. Hearts from transgenic pigs constructed with CD59/DAF genomic clones demonstrate improved survival in primates. Xenotransplantation 6, 194-200.

Christian M., CERMAK T., DOYle E. L., SCHMidT C., ZHANG F., Hummel A. i współaut., 2010. Targeting DNA double-strand breaks with TAL effector nucleases. Genetics 186, 757-761.

CIERPKA L., BUDZIŃSKI G., 2013. Ograniczenia $i$ wyzwania ksenotransplantacji [W:] Biotechnologiczne $i$ medyczne podstawy ksenotransplantacji. SMORAG Z., SŁOMSKI R., CIERPKA L. (red.). Ośrodek Wydawnictw Naukowych ICB PAN, Poznań

Collins H. C., 2003. Transplantation. What is the State of the Art? Ann. Surgery 238, 73-89.

CONG L., RAN F. A., COX D., LiN S., BARRETTO R., HABIB N. i współaut., 2013. Multiplex genome engineering using CRISPR/Cas systems. Science $339,819-823$

COOPER D. K. C., BOTTINO R., 2015. Recent advances in understanding xenotransplantation: implications for the clinic. Exp. Rev. Clin. Immunol. 11, 1379-1390.

COOPER D. K., KOREN E., ORIOL R., 1993. Genetically engineered pigs. Lancet 342, 682-683

COOPER D. K. C., SATYANANDA V., EKSER B., VAN DER WINDT D. J., HARA H., EZZELARAB M., SchuURMAN H.-J., 2014. Progress in pig-to-nonhuman primate transplantation models (1998-2013): a comprehensive review of the literature. Xenotransplantation 21, 397419.

Cozzi E., Bhatti F., Schmoeckel M., Chavez G., SMiTH K. G., ZAIDI A. i współaut., 2000. Long term survival of nonhuman primates receiving 
life-supporting transgenic porcine kidney xenografts. Transplantation 70, 15-21.

DENNER J., 2008. Is porcine endogenous retrovirus (PERV) transmission still relevant? Transplant. Proc. 40, 587-589.

DENNER J., 2010. Recombinant porcine endogenous retroviruses (PERV-A/C): a new risk for xenotransplantation? Xenotransplantation 17, 120-120.

DENNER, J., TÖNJES R. R., 2012. Infection barriers to successful xenotransplantation focusing on porcine endogenous retroviruses. Clin. Microbiol. Rev. 25, 318-343.

DepPenMeIER S., BOCK O., Mengel M., NiEMANN H., Kues W., Lemme E. i współaut., 2006. Health status of transgenic pigs expressing the human complement regulatory protein CD59. Xenotransplantation 13, 345-356.

DiAMOND L. E., MCCURRY K. R., MARTIN M. J., MCClellan S. B., Oldham E. R., Platt J. L., LOGAN J. S.,1996. Characterization of transgenic pigs expressing functionally active human CD59 on cardiac endothelium. Transplantation 61, 1241-1249.

DiAMOND L. E., QUiNN C. M., MARTin M. J., LAWSON J., PlatT J. L., LOGAN J. S., 2001. A human CD46 transgenic pig model system for the study of discordant xenotransplantation. Transplantation 71, 132-142.

Durai S., Mani M., Kandavelou K., Wu J., PoRTEUS M. H., ChandRASEgaRAN S., 2005. Zinc finger nucleases: custom-designed molecular scissors for genome engineering of plant and mammalian cells. Nucl. Acids Res. 33, 59785990.

Dwye K. M., MYsore T. B., CRIKIS S., RoBson S. C., NANDURKaR H., COWAN P. J., D'APICE A. J., 2006. The transgenic expression of human CD39 on murine islets inhibits clotting of human blood. Transplantation 82, 428-432.

Ekser B., Burlak C., WALDMAN J. P., LuTZ A. J., PARIS L. L., VEROUX M. i współaut., 2012. Immunobiology of liver xenotransplantation. Exp. Rev. Clin. Immunol. 8, 621-634.

FODOR W. L., Williams B. L., Matis L. A., MADRI J. A., Rollins S. A. i współaut., 1994. Expression of a functional human complement inhibitor in a transgenic pig as a model for the prevention of xenogeneic hyperacute organ rejection. Proc. Natl. Acad. Sci. USA 91, 1115311157.

GALILI U., 1993. Interaction of the natural anti-Gal antibody with a-galactosyl epitopes: a major obstacle for xenotransplantation in humans. Immunol. Today 14, 480-482.

GaLILI, U., 2001. The a-gal epitope (Gala 1-3Galß 1$4 G l c N A c-R)$ in xenotransplantation. Biochimie, 83, 557-563.

GALILI U., SWANSON K., 1991. Gene sequences suggest inactivation of alpha-1, 3-galactosyltransferase in catarrhines after the divergence of apes from monkeys. Proc. Natl. Acad. Sci. USA 88, 7401-7404.

Galili U., Rachmilewitz E. A., Peleg A., FlechNER I., 1984. A unique natural human IgG antibody with anti-a-galactosyl specifi city. J. Exp. Med. 160, 1519-1531.

Galili U., Shohet S. B., Kobrin E., Stults C. L., MACHER B. A., 1988a. Man, apes, and Old World monkeys differ from other mammals in the expression of alpha-galactosyl epitopes on nucleated cells. J. Biol. Chem. 263, 1775517762.

Galili U., MANDREll R. E., HAMAdeh R. M., ShoHET S. B., GRIFFISS J. M., 1988b. Interaction between human natural anti-alpha-galactosyl immunoglobulin $G$ and bacteria of the human flora. Infect. Immunity 56, 1730-1737.

Gemeniano M., Mpanju O., Salomon D. R., Eiden M. V., WILSON C. A., 2006. The infectivity and host range of the ecotropic porcine endogenous retrovirus, PERV-C, is modulated by residues in the C-terminal region of its surface envelope protein. Virology 346, 108-117.

HARRISON I., TAKEUCHI Y., BARTOSCH B., STOYE, J. P., 2004. Determinants of high titer in recombinant porcine endogenous retroviruses. J. Virol. 78, 13871-13879.

IDE K., Wang H., TAHaRa H., LiU J., Wang X. i współaut., 2007. Role for CD47-SIRPa signaling in xenograft rejection by macrophages. Proc. Natl. Acad. Sci. USA 104, 5062-5066.

KAY S., BONAS U., 2009. How Xanthomonas type III effectors manipulate the host plant. Curr. Opin. Microbiol. 12, 37-43.

KimSA-DUdEK M., STRZALKA-MROZIK B., KIMSA M. W., Blecharz I., Gola J. i współaut., 2015. Screening pigs for xenotransplantation: expression of porcine endogenous retroviruses in transgenic pig skin. Transgen. Res. 24, 529536.

Kopp C. W., Siegel J. B., Hancock W. W., ANRATHER J., WINKLER H., GECZY C. L. i współaut., 1997. Effect of porcine endothelial tissue factor pathway inhibitor on human coagulation factors. Transplantation 63, 749758.

Le Bas-Bernardet S., Tillou X., Poirier N., DileK N., Chatelais M., i współaut., 2011. Xenotransplantation of galactosyl-transferase knockout, CD55, CD59, CD39, and fucosyl-transferase transgenic pig kidneys into baboons. Transplant. Proc. 43, 3426-3430.

Le Tissier P., Stoye J. P., TAKeuchi Y., PATIENCE C., WeISS R. A., 1997. Two sets of human-tropic pig retrovirus. Nature 389, 681682.

LilienfEld B. G., CREW M. D., FORTE P., BAUMANN B. C., SEEBACH J. D., 2007. Transgenic expression of HLA-E single chain trimer protects porcine endo-thelial cells against human natural killer cell-mediated cytotoxicity. Xenotransplantation. 14, 126-134.

LIPIŃSKI D., JURA J. ZEYLAND J., JUZWA W., MAEY E., KALAK R. i współaut., 2010. Production of transgenic pigs expressing human a 1, 2-fucosyltransferase to avoid humoral xenograft rejection. Med. Wet. 66, 316-322.

LIPIŃSKI D., ZEYLAND J., BOKSA M., NOWAK A., PRZYSTAŁOWSKA H., PŁaWsKI A., SZALATA M., SMORAG Z., SŁOMSKI R., 2013. Transgeneza dla potrzeb ksenotransplantacji. [W:] Biotechnologiczne $i$ medyczne podstawy ksenotransplantacji. SMORAG Z., SŁOMSKI R., CIERPKA L. (red.). Ośrodek Wydawnictw Naukowych ICB PAN, Poznań, 55-67.

LOVEland B. E., Milland J., KYRIAKOU P., THORLEY B. R., Christiansen D., LANTERI M. B. i współaut., 2004. Characterization of a CD46 transgenic pig and protection of transgenic kidneys against hyperacute rejection in non-immunosuppressed baboons. Xenotransplantation 11, 171-183.

MAZUREK U., KIMSA M. W., STRZALKA-MrOZIK B., KIMSA M. C., KRUSZNIEWSKA-RAJS C. i wspó1aut., 2014. Microarray analysis of retroviral restriction factor gene expression in response to porcine endogenous retrovirus infection. Pol. J. Microbiol. 63, 183-190.

McCurRy K. R., KoOyman D. L., Alvarado C. G., CotTEREll A. H., MARTIN M. J., LOGAN J. S., PlatT J. L., 1995. Human complement regu- 
latory proteins protect swine-to-primate cardiac xenografts from humoral injury. Nat. Med. 1, 423-427.

MiCHLER R. E., 1996. Xenotransplantation: risks, clinical potential, and future prospects. Emerg. Infect. Dis. 2, 64-70.

Miller J. C., Holmes M. C., Wang J., Guschin D. Y., LEE Y. L., RUPNIEWSKI I. i współaut., 2007. An improved zinc-finger nuclease architecture for highly specific genome editing. Nat. Biotechnol. 25, 778-785.

NiEMANN H., VERHOEYEN E., WONIGEIT K., LORENZ R., HECKER J., SCHWINZER R. i współaut., 2001. Cytomegalovirus early promoter induced expression of hCD59 in porcine organs provides protection against hyperacute rejection. Transplantation 72, 1898-1906.

OPTN (Organ Procurement and Transplantation Network), 2017. https://optn.transplant.hrsa. gov/.

PENNISI E, 2013. The CRISPR craze. Science 341, 833-836.

POLTRANSPLANT, 2015. Biuletyn Informacyjny. http: / www.poltransplant.pl/Download/biuletyn2015_www.pdf.

REEMTSMA K., 1966. Renal heterotransplantation. Adv. Surg. 2, 285-293.

SACKS S. H., ZHOU W., 2012. The role of complement in the early immune response to transplantation. Nat. Rev. Immunol. 12, 431-442.

SAMDANI T., 2004. Xenotransplantation. http:// emedicine.medscape.com/article/432418-overview.

SEgA P., Linkiewicz A., 2014. Wykorzystanie miejscowo-specyficznych nukleaz do modyfikacji genomów roślinnych. Post. Biol. Kom. 41, 701-720.

Siegel J. B., Grey S. T., LesniKoski B. A., KopP C. W., SOARES M., JAN SCHUlTE EsCH I. I. i współaut., 1997. Xenogeneic Endothelial Cells Activate Human Prothrombin1, 2. Transplantation 64, 888-896.

SŁOMSKI R., SMORAg Z., CieRPKA L., 2013. Wstęp [W:] Biotechnologiczne $i$ medyczne podstawy ksenotransplantacji. SMORAG Z., SŁOMSKI R., CIERPKA L. (red.). Ośrodek Wydawnictw $\mathrm{Na}$ ukowych ICB PAN, Poznań, 9-10.

Startzl T. E., Fung J., Tzakis A., Todo S., DemeTRIS A. J., MARINO I. R., DOYLE H., ZEEVI A., WARTY V., MichaEls M., 1993. Baboon-to-human liver transplantation. Lancet 341, 65-71.

SuCHANOWSKA A., CZERWIŃSKI M., 2009. Dlaczego $u$ człowieka $i$ małp waskonosych nie ma epitopu Gala1-3Gal, którego obecność u zwierzat jest zwiazana $z$ odrzucaniem ksenoprzeszczepów u ludzi? Post. Hig. Med. Dosw.. 63, 250257

Tilney N. L., 2005. Przeszczep. Od mitów do rzeczywistości. Medical Science International. Sp. z o.o., Warszawa.

WATERWORTh P. D., DUNNing J., TOlan M., CozzI E., LANGFORD G., CHAVEZ G. i współaut., 1998. Life-supporting pig-to-baboon heart xenotransplantation. J. Heart Lung Transplant. $17,1201-1207$.

Wilson C. A., Wong S., VANBrocklin M., FederSPIEL M. J., 2000. Extended analysis of the in vitro tropism of porcine endogenous retrovirus. J. Virol. 74, 49-56.

Yi S., HaWTHORNe W. J., Lehnert A. M., Ha H. WONG J. K. W., VAN ROOIJEN N. i współaut., 2003. T cell-activated macrophages are capable of both recognition and rejection of pancreatic islet xenografts. J. Immunol. 170, 27502758.

ZEYLAND J., GaWrońska B., JUZWA W., JURA J., NOWAK A., SŁOMSKI R. i współaut., 2013. Transgenic pigs designed to express human a-galactosidase to avoid humoral xenograft rejection. J. Appl. Genet. 54, 293-303.

ZEYLAND J., WOŹNIAK A., GAWROŃSKA B., JUZWA W., JURA J., NOWAK A. i współaut., 2014. Double transgenic pigs with combined expression of human a 1, 2-fucosyltransferase and a-galactosidase designed to avoid hyperacute xenograft rejection. Arch. Immunol. Therap. Exp. 62, 411-422. 
KOSMOS Vol. 67, 3, 541-553, 2018

\section{JERZY WIATER}

Department of Cell Biology and Imaging, Institute of Zoology and Biomedical Research, Jagiellonian University in Krakow, 9 Gronostajowa Str., 30-387 Kraków, E-mail: jerzy.wiater@uj.edu.pl

\section{WOULD XENOTRANSPLANTATION BECOME A REALITY DUE TO GENETIC ENGINEERING METHODS? TRANSGENIC PIGS AS POTENTIAL DONORS OF ORGANS FOR HUMAN}

\section{Summary}

Shortage of organ donors poses now a serious problem in transplantology. Many patients die every year waiting unsuccessfully for a transplant. Is there an alternative to human organs? The use of animals as donors of cells, tissues and organs can be the answer to this question. However, selection the best species is difficult. The apes, which are genetically closest to humans, unfortunately do not meet many criteria. In addition, they raise a lot of ethical controversies. The pig, which is physiologically and genetically similar to human, seems to be an optimal donor. However, the limitation is an immunological barrier, resulting from the greater phylogenetic distance between the pig and human. Modern genetic engineering is trying to solve this problem. It is possible to obtain transgenic pigs that have in their genome human genes that reduce the risk of tissue and immune incompatibility. This article provides an overview of the genetic engineering of domestic pigs for xenotransplantation. Several strategies have been explored to tackle the problem of xenograft rejection and indicated possible opportunities and risks associated with the use of animal derived materials.

Key words: pig, transgenesis, xenotransplantation 